\title{
PRINSIP-PRINSIP GATS (GENERAL AGREEMENT ON TRADE IN SERVICES) TERHADAP PERDAGANGAN JASA PENDIDIKAN TINGGI
}

\author{
Oleh:
}

Alberta Hartiana ${ }^{1}$

\begin{abstract}
Trade in higher education has become global trend and reform in systemof higher education all over the world. This research is aimed at finding out both modes of supply and principles of GATS regarding international trade in services. The main objective of the GATS is creating a credible trading system to services, ensuring fair and equitable treatment of all members, stimulating economic activity through guaranteed policy bindings, promoting trade and development through progressive liberalization. This study used normative research. The method used for collecting data was the statute approach. Primary legal sources derived from WTO Trade in Services Division regarding GATS obligations and the principles of the international trade in services. The result of this study, it was found that, there were four modes of supply trade in education under GATS (article 1:2) such as: cross-border supply; consumption abroad; commercial presenceanddelivery abroad; and the principles of GATSdivided into two categories;Firstly, unconditionally obligations, such as the Most-Favoured Nation(article II GATS) and Transparency (article III GATS)are applied directly and automatically to all WTO members regardless of whether specific commitment have been made or not;Secondly, conditionally obligations such as: National Treatment (article XVII) and Market Access (article XVI) are only applied in services sectors/sub-sectors listed in the specific national commitment have been made.
\end{abstract}

Keywords: trade in higher education, modes of supply, GATS's principles

\begin{abstract}
Abstrak
Perdagangan jasa pendidikan tinggi telah menjadi tren global dan mereformasi sistem pendidikan tinggi di seluruh dunia.Penelitian ini bertujuan untuk mengetahui model-model pasokan dan prinsip-prinsip GATS mengenai perdagangan internasional di bidang jasa.Tujuan utama dari GATS adalah menciptakan sistem perdagangan jasa yang terpercaya, memastikan perlakuan yang adil dan merata bagi semua anggotanya, merangsang kegiatan ekonomi melalui jaminan kebijakan yang mengikat, mempromosikan perdagangan dan pembangunan melalui liberalisasi progresif. Penelitian ini menggunakan penelitian normatif.Metode yang digunakan untuk mengumpulkan data adalah pendekatan undang-undang.Sumber hukum yang utama berasal dari WTO Perdagangan Jasa Divisi mengenai kewajiban-kewajiban GATS dan prinsipprinsip perdagangan internasional di bidang jasa.Hasil penelitian ini, ditemukan

1 Mahasiswa Magister (S2) Ilmu Hukum Universitas Udayana, Denpasar-Bali, Alamat: Br. Saba Desa Saba Kec. Blahbatuh, Kab.Gianyar,email:sendtoberta@gmail.com
\end{abstract}


bahwa, ada empat model perdagangan jasa pendidikan di bawah GATS (pasal 1: 2) melalui empat model pasokan yaitu: model 1) pasokan lintas batas; model 2) Konsumsi di luar negeri; model 3) Kehadiran komersialdan model 4) pengiriman luar negeri; dan prinsip-prinsip GATS dibagi menjadi dua kategori;Pertama, kewajiban tanpa syarat, yaitu Most favoured Nation Treatment (pasal II GATS) dan Transparansi (pasal III GATS) yang diterapkan secara langsung dan otomatis terhadap semua anggota WTO terlepas dari apakah para anggota WTO telah membuat komitmen khusus atau belum; Kedua kewajiban dengan kondisional seperti: Perlakuan Nasional (pasal XVII) dan Akses Pasar (pasal XVI) hanya diterapkan terhadap daftar sektor-sektor jasa / sub-sektor yang tercantum dalam komitmen khusus nasional yang telah dibuat.

\section{Kata kunci: perdagangan jasa pendidikan tinggi, model pasokan, prinsip GATS}

\section{PENDAHULUAN}

Negara-negara industri yang tergabung dalam organisasimultilateral The Organization for Economic Cooperation and Development (OECD) ${ }^{2}$ yang juga merupakan anggota WTO (World Trade Organization), sepakat untuk mencantumkan sektor pendidikan menjadi salah satu sektor jasa dalam perdagangan internasional di bawah kerangka GATS (General on Trade in Services), pada Uruguay Round I januari 1995. GATS adalah organisasiinternasional,yangmengatur tentang kerangka hukum dan prinsipprinsip terhadap sistemperdagangan internasional di bidang jasa secara multilateral. ${ }^{3}$ Tujuan utama GATS adalah menciptakan sistem aturan perdagangan internasional kredibel dan terpercaya; kepastian atas perlakuan yang adil dan merata bagi

2 OECD/CERI, 2002, Current Commitments under the GATS in Educational Services, Washington, DC, U.S.A., hlm. 7

3 WTO, 2013, The General Agreement on Trade in Services an Introduction, Trade in Services Division, hlm.1 semua negara anggota; merangsang kegiatan ekonomi melalui jaminan kebijakanyang mengikat serta mempromosikan perdagangan dan pembangunan melalui liberalisasi progresif. $^{4}$

Pada prinsipnya perdagangan internasional di bidang jasa pendidikan tinggi sama dengan sistem perdagangan pada sektor jasa-jasa yang lain di bawah GATS. Para pihak yang terdapat dalam perdagangan jasa pendidikan tinggi terdiri dari: negara pengekspor (those who provide higher education to foreign nationals) dan negara pengimpor (those who consume higher education provided by a foreign supplier). ${ }^{5}$

4 Jandhyala B.G. Tilak, 2011, Trade in Higher Education: The Role of The Agreementon Trade in Services (GATS), UNESCO: International Institute for Educational Planning, Paris, hlm. 32

5 Sajitha Bashir, 2007, Trend in International Trade in Higher Education: Implications and Options for Developing Countries, Copyright (C) The World Bank, Washington, D.C. U.S.A. hlm. 6-7 
Negara-negara anggota WTO melalui document MTN.GNS/ $\mathrm{W} / 120{ }^{6}$ telah menetapkan sistem klasifikasi 12 sektor jasa yang terdiri dari: 1) Business services; (including professional services and computer services); 2) Communication services; 3) Construction and related engineering services; 4) Distribution services; 5) Jasa Educational services; 6) Jasa Lingkungan (Environmental services); 7) Financial services; including insurance and banking); 8) Health-related and social services; 9) Jasa Tourism and travel-related services; 10) Recreational, cultural and sporting services; 11) Transport services; 12 Other(services not included elsewhere).

Di dalam penulisan ini, topik yang diangkat adalah mengenai modelmodel (modes of supply) perdagangan jasa pendidikan tinggi menurut GATS serta prinsip-prinsip yang diterapkan di dalam perdagangan jasa pendidikan tinggi.

Dari latar belakang masalah tersebut di atas, maka dalam tulisan ini penulis mengemukakan dua rumusan masalah yakni:

1. Bagaimana model-model (modes of supply) perdagangan jasa pendidikan tinggi menurut GATS?

2. Bagaimana prinsip-prinsip GATS terhadap perdagangan jasa pendidikan tinggi?

$6 \quad$ Ibid, hlm. 4

\section{Orisinalitas Penelitian}

Penelitian ini belum pernah dilakukan oleh peneliti lainnya, akan tetapi secara garis besar terdapat beberapa penelitian yang mempunyai korelasi dengan penelitian aktual, yaitu:

1. Penelitian dalam jurnal yang ditulis oleh AnggiatP. Simamora, Bismarnasution, Suhaidi, MahmulSiregar, dari USU Law Journal, Vol.II-No.1 (Februari, 2014) 67-89 yang berjudul "Liberalisasi Pendidikan Dalam Kerangka GATS: Kajian Hukum Terhadap Pendirian Perguruan Tinggi Asing Di Indonesia". Penelitian jurnal ini menguraikan tentang dampak WTO/GATS yang telah mendistorsi sifat pendidikan sebagai layanan publik di Indonesia dengan mengemukakan pertanyaanpertanyaan mengenai permasalahan tentang dampak GATS terhadap pengaturan pendidikan tinggi di Indonesia danpengaturan pendirianinstitusi pendidikan tinggi asing di dalam regulasi nasional.Persamaan dengan penelitian aktual adalah sama-sama mengkaji tentang perdagangan jasa pendidikan tinggi.Perbedaannya adalah peneliti mengkaji dan menganalisis tentang modelmodel pasokan (modes of supply) terkait perdagangan di dalam jasa pendidikan tinggi 
yang ditentukan oleh GATS dan penerapan prinsip-prinsip GATS terhadap perdagangan jasa pendidikan tinggi.

2. Penelitian dalam jurnal yang ditulis oleh Philip G. Altbach and Jane Knight dari Journal of Studies in International Education 2007 11:290 DOI: 10 $.1177 / 1028315307303542$, yang berjudul "The International of Higher Education: Motivations and Realities". Jurnal ini membahas tentang perbedaan globalisasidaninternasionalisasi, di mana globalisasi didefinisikan dalam konteks tren ekonomi dan akademis yang merupakan bagian dari realitas abad ke21.Sedangkan internasionalisasi meliputi kebijakan dan praktik yang dilakukan oleh sistem akademik dan lembaga-lembaga swasta untuk mengatasi lingkungan akademik global. Di uraikan juga bahwa motivasi internasionalisasi adalah bertujuan untuk mendapatkan keuntungan komersial, transfer ilmupengetahuandanpenguasaan bahasa, meningkatkan kurikulum dengan konten internasional. Selanjutnya, inisiatif khusus terhadap kampus cabang, pengaturan kerja sama lintas batas, program untuk siswa internasional, mendirikan program bahasa inggris pada sekolah menengah dan sederajat merupakan bagian dari internasionalisasi. Hal ini sebagai upaya untuk memantau inisiatif internasional dan jaminan kualitas sebagai bagian integral dari pendidikan tinggi internasional.Persamaan dengan penelitian aktual adalah sama-sama mengkaji tentang perdagangan jasa pendidikan tinggi.Perbedaannya adalah peneliti mengkaji dan menganalisis tentang modelmodel pasokan (modes of supply) terkait perdagangan di dalam jasa pendidikan tinggi yang ditentukan oleh GATS dan penerapan prinsip-prinsip GATS terhadap perdagangan jasa pendidikan tinggi.

Penelitian tentang PrinsipPrinsip GATS (General Agreement on Trade in Services) Terhadap Perdagangan Jasa Pendidikan Tinggi mempunyai Tujuan Umum dan Tujuan Khusus.

1. Tujuan Umum: Untuk mengetahui model-model (mode of supply) perdagangan jasa pendidikan tinggi menurut GATS.

2. Tujuan Khusus: Tujuan khusus dari Penelitian ini berkaitan dengan 'Science as a product' yaitu mendeskripsikan dan menganalisa secara mendalam tentang ketentuan-prinsipprinsip GATS sehubungan dengan perdagangan jasa pendidikan tinggi. 


\section{METODE PENELITIAN}

\subsection{Jenis Penelitian}

Jenis Penelitian yang digunakan dalam penulisan ini adalah jenis Penelitian hukum normatif, karena meneliti asas-asas serta kaidah hukum.Asas-asas serta kaidah hukum ketentuan-ketentuan WTO yang mengatur tentang perdagangan internasional multilateral, yang menaungi perjanjian GATS berkaitan dengan perdagangan jasa pendidikan tinggi.

\subsection{Sifat Penelitian}

Penelitian mengenai perdagangan jasa pendidikan tinggi yang diberlakukan oleh WTO melalui ketentuan-ketentuan di bawah GATS adalah bersifat deskriptif kualitatif yaitu menggambarkan model-model (mode of supply)dalam perdagangan jasa pendidikan tinggi berdasarkan GATS, kemudian dikaitkan dengan pengaturan prinsip-prinsip GATS yang diterapkan dalam perdagangan jasa pendidikan tinggi.

\subsection{Sumber Bahan Hukum}

Sumber bahan hukum yang dipergunakan dalam Penelitian ini meliputi bahan hukum primer berupa konvensi GATS yang mengatur tentang model-model (mode of supply) dan prinsip-prinsip GATS terhadap perdagangan jasa pendidikan tinggi. Sumber bahan hukum sekunder berupa bahan hukum yang dapat memberikan penjelasan mengenai bahan hukum primer seperti hasil-hasil Penelitian, hasil karya ilmiah di bidang hukum, literatur hukum dan sebagainya.Bahan hukum tersier berupa kamus dan buku pegangan (hand out). ${ }^{7}$

\subsection{Teknik Pengumpulan Bahan}

Metode pengumpulan bahan hukumnya diperoleh melalui metode pengumpulan bahan dengan cara mengumpulkan peraturan perundangundangan, konvensi-konvensi internasional, literatur-literatur, jurnal hukum ${ }^{8}$ dan lain sebagainya yang terkait dengan permasalahan model-model dan prinsip-prinsip GATS, kemudian dilanjutkan dengan penyortiran bahan-bahan tersebut terkait dengan permasalahan.

\subsection{Teknik Pengolahan dan Analisa Bahan Hukum}

Teknik pengolahan bahan hukum dalam Penelitian ini dengan mengolah bahan hukum secara kualitatif artinya bahan-bahan hukum yang relevan diolah dengan melihat kualitas kegunaan.

III. HASIL DAN PEMBAHASAN

3.1 Perdagangan Jasa Pendidikan Tinggi Dalam Kerangka GATS

Berdasarkan article 1:2 GATS bahwa perdagangan di bidang pendidikan diperbolehkan di bawah

7 SoerjonoSoekanto, 2006, Pengantar Penelitian Hukum, UI Press, Jakarta, hlm. 52

8 Johny Ibrahim, 2005, Teori dan Metodologi Penelitian Hukum Normatif, Bayu Media, Malang, hlm. 284 
empat model (four modes of supply) yaitu: ${ }^{9}$

Model 1'Cross-Border Supply', adalah pasokan jasa pendidikan dari wilayah satu negara anggota ke dalam wilayah negara anggota lainnya. Di dalam model ini, tidak ada perpindahan (mobilitas) fisik antara penjual maupun konsumen. Hanya mobilitas 'jasa' misalnya, jarak atau program pendidikan virtual melalui surat, telepon, atau televisi, atau program berbasis web pendidikan dan pelatihan (e-learning) seperti yang banyak ditawarkan oleh universitas AS terhadap negara-negara berkembang (developing countries). Hal ini mengacu pada penjualan program pendidikan / pelatihan dan cakupannya secara luas, melalui internet dan media elektronik seperti CD-ROM dan DVD. Jadi Model 1, hanya mobilitas program (program mobility).

Model2: 'Consumptionabroad' adalah penyediaan jasa pendidikan di wilayah satu negara anggota untuk konsumen dari negara anggota lainnya. Di dalam model ini, penjual tetap berada di negaranya dan konsumen yang melakukan perjalanan/pindah ke negara lain, untuk mengkonsumsi jasa yang diberikan.Dalam pendidikan; model ini mengacu pada mobilitas siswa (student mobility) di mana orang pergi ke luar negeri untuk belajar di universitas tradisional sebagai siswa reguler.Model ini adalah bentuk internasionalisasi paling umum dalam kategori tradisional dan modern.

9 Jandhyala B.G. Tilak, op.cit, hlm. 33-35
Model3: 'Commercialpresence', adalah pasokan jasa dengan pemasok jasa suatu negara anggota melalui kehadiran komersial di wilayah negara anggota lain, yaitu, pembentukan sebuah lembaga pendidikan, cabang, dan anak perusahaan luar negeri. Pembukaan wara laba luar negeri, usaha patungan, dan 'Twinning' baik secara internasional maupun secara regional.Pengaturan antara lembaga pendidikan dari berbagai negara masuk kategori ini.Wara laba bisa seluruhnya atau parsial (ada pembatasan).Ketika kampus telah ditetapkan, biasanya lembaga asing menetapkan anak perusahaan baik sendiri atau bersamasama dengan penyedia lokal, tetapi dalam kedua jenis ini, jasa disampaikan seluruhnya oleh universitas asing. Dalam kasus wara laba (franchise), penyedia pendidikan asing mendesain program dan penyampaiannya dilakukan oleh mitra di negara lain. Pada dasarnya, di dalam model ini tidak ada mobilitas konsumen, namun ada mobilitas lembaga dan investasi asing langsung (foreign direct investment). Pengaturan 'Twinning' dan usaha patungan yang dibentuk berdasarkan model ini memungkinkan siswa mengikuti program sebagian di negara mereka sendiri dan sebagian di negara asing.Kemudian, gelar ini diberikan oleh lembaga asing atau bersama-sama dengan dua lembaga (dual degree).

Model 4: 'Presence of natural persons' adalah perpindahan penyedia jasa lintas batas negara yang bersifat 
sementara, dalam kapasitas individu atau sebagai bagian dari suatu institusi yang menyediakan jasa untuk di luar negeri seperti profesional software (perangkat lunak), insinyur, dokter, ilmuwan, penasehat, perencana, dan model, dan sebagainya, termasuk tenaga kerja terampil maupun tidak terampil. Terkait dengan pendidikan, hal ini dikategorikan seperti guru dan administrator pendidikan yang pergi ke suatu negara untuk bekerja sebagai tenaga pendidik, maupun sebagai tenaga administrasi.Dengan kata lain, model ini dapat disebut sebagai mobilitas orang (tenaga kerja), tetapi berbeda dengan Model 2, karena tidak ada mobilitas siswa.

\subsection{Prinsip-Prinsip GATS Terhadap Perdagangan Jasa Pendidikan Tinggi}

Berikut ini prinsip-prinsip penting di dalam GATS terkait dengan perdagangan jasa yaitu: ${ }^{10}$

A. Prinsip 'most favoured nation' (MFN) dan 'Transparency'. yang merupakan kewajiban umum (unconditional obligations). Prinsip 'Most favoured Nation' diaplikasikan secara langsung dan otomatis bagi seluruh negara anggota WTO dan sektor-sektor jasa ${ }^{11}$ sesuai dengan yang diatur dalam article II:1 GATS bahwa,'With respect to any measure covered by this Agreement, each Member shall accord immediately and unconditionally to service dan

10 Ibid, hlm. 37-38

11 OECD, op.cit, h. 5 service suppliers of any other Member treatment no less favourable than that it accords to like services and service supplier of any other country.'Prinsip 'Transparency' diatur dalam article III GATS yang memastikan bahwa semua negara-negara anggota WTO mempublikasikan semua kebijakankebijakan/peraturan perundangundangan yang ada hubungannya/ relevansi dengan perdagangan jasa, termasuk tentang 'limitation' dan 'restriction.'Terkait dengan perdagangan di dalam sektor pendidikan bahwa semua negaranegara anggota harus mendapat perlakuan yang sama. Misalnya, apabila suatu perguruan asing dari negara anggota WTO mendirikan kampus di suatu negara anggota, maka hal ini berlaku juga bagi negaranegara anggota yang lain. Berdasarkan prinsip'Most favoured nation; berarti tidak boleh ada perlakuan diskriminasi antar negara-negara anggota;

B. Prinsip 'National Treatment' (article XVII GATS) dan 'Market Access'article XVI GATS) yang merupakan kewajiban dengan persyaratan (conditional obligations), hanya diaplikasikan terhadap daftar komitmen di dalam jadwal nasional ${ }^{12}$. Terkait dengan perdagangan jasa pendidikan tinggi artinya memberikan perlakuan yang sama kepada lembaga pendidikan nasional dan lembaga pendidikan asing yang didirikan di suatu negara anggota, dalam hal subsidi

12 Ibid 
dan kondisi lain. Berdasarkan prinsip 'national treatment' artinya tidak boleh ada perlakuan diskriminasi terhadap lembaga pendidikan asing maupun lembaga pendidikan domestik.

Selanjutnya prinsip 'market access' diatur dalam article XVI GATS, merupakan kewajiban dengan persyaratan (conditional obligations) di mana mensyaratkan negara untuk melaksanakan liberalisasi progresif dengan menghapus hambatanhambatan bagi universitas asing dalam mengakses pasar sektor jasa pendidikan di negara-negara anggota WTO. Berdasarkan prinsip 'market access' maka tidak diperbolehkan menghambat masuknya perguruan tinggi asing ke dalam pasar domestik maupun melarang mahasiswa untuk mengakses pendidikan di dalam negara-negara anggota WTO.

\section{KESIMPULAN}

Berdasarkan uraian pembahasan di atas, maka dapat disimpulkan sebagai berikut:

1. Pendidikan Tinggi merupakan sub-sektor jasa pendidikan yang diatur dalam perdagangan internasional di bidang jasa di bawah kerangka GATS (General Agreement on Trade in Services)melalui empat model pasokan (four modes of supply) sesuai dengan pasal 1:2 GATS yaitu: model 1) cross-border supply; model

2) consumption abroad; model
3) commercial presence dan; model 4) presence of natural persons.

2. Prinsip-prinsip GATS dibagi menjadi dua kategori;Pertama, kategori kewajiban t a n p a syarat, yaitu: Most-Favoured Nation(pasal II GATS) dan Transparency (pasalIIIGATS) berlaku secara langsung dan otomatis kepada semua anggota WTO dan sektor jasa terlepas dari apakah anggota WTO membuat jadwal komitmen atau tidak; Kedua, kewajiban dengan persyaratan seperti: Perlakuan Nasional (pasal XVII) dan Akses Pasar (pasal XVI); hanya diaplikasikan terhadap daftar sektor-sektor jasa yang tercantum dalam jadwal khusus komitmen nasional.

\section{DAFTAR PUSTAKA}

\section{Buku}

Jandhyala B.G. Tilak, 2011, Trade in Higher Education: The Role of The Agreement onTrade in Services (GATS), UNESCO: International Institute for EducationalPlanning, Paris Johny Ibrahim, 2005, Teori dan Metodologi Penelitian Hukum Normatif, Bayu Media, Malang OECD/CERI, 2002, Current Commitments under the GATS in Educational ServicesWashington, DC, U.S.A. 
Sajitha Bashir, 2007, Trend in International Trade in Higher Education: Implications and Options for Developing Countries, Copyright (C) The World Bank, Washington, D.C. - U.S.A.

SoerjonoSoekanto, 2006, Pengantar Penelitian Hukum, UI Press, Jakarta

WTO, Trade in Services Division, 2013, The General Agreement on Trade in Services an Introduction

\section{Peraturan-Peraturan Internasional}

Agreement Establishing the World Trade Organization (WTO)

GATS (The General Agreement on Trade in Services)

WTO (World Trade Organization).

\section{Jurnal}

AnggiatP.Simamora, BismarNasution, Suhaidi, MahmulSiregar, dari USU Law Journal, Vol.IINo.1 (Februari, 2014) 67-89 yang berjudul "Liberalisasi Pendidikan Dalam Kerangka GATS: Kajian Hukum Terhadap Pendirian Perguruan Tinggi Asing Di Indonesia." Available at: http://download.portalgaruda. org/article.php?article $=147248$ $\&$ val $=4099 \&$ title $=$ LIBERALIS ASI\%20PENDIDIKAN\%20DA LAM\%20KERANGKA\%20GA TS\%20:\%20KAJIAN\%20HUK UM\%20TERHADAP\%20PEN
DIRIAN\%20PERGURUAN\%2 0TINGGI\%20ASING\%20DI\% 20INDONESIA.

Philip G. Altbach and Jane Knight dari Journal of Studies in International Education 2007 11:290 DOI: 10 $.1177 / 1028315307303542$, yang berjudul "The International of Higher Education: Motivations and Realities". Available at http://journals.sagepub.com/doi/ pdf/10.1177/102815307303542. 